\title{
HOW TO ALIGN ORGANIZATIONAL CULTURE WITH CORPORATE GOALS: A STUDY ON A LARGE-SIZED BRAZILIAN ENGINEERING COMPANY
}

Maria Augusta de Castro

\section{Seixas}

gtseixas@gmail.com

Emmanuel Paiva de Andrade (1) emmanueluff@gmail.com

João Carlos Cândido

joaoccandido@gmail.com

Rosa Amélia Pizzol

rosameliap@bol.com.br

\section{ABSTRACT}

Goal: What a company produces and how it does is permeated by belief, thought and shared feelings in the employees. The goal of this study is to construct an explanation on how this phenomenon manifests itself in an engineering company.

Design / Methodology / Approach: The qualitative approach was adequate to understand how elements of individual narratives were related to the company culture. The analytical procedures were based on the systematics of Grounded Theory. Texts written in 2016 by the employees about their work for applying for a knowledge management program within their company were the source of this corpus.

Results: The interpretation of the data has shown that four aspects form sets of filters that construct the culture, in a non-homogeneous learning process. In the intersection of these sets we can find essential values that motivate the employees of different positions, activities, regions, genders and ages.

Limitations of the investigation: The knowledge management program asked for overcoming stories which is a limiting factor since employees have chosen successful stories from their work to tell.

Practical implications: The findings allow us to infer that changing or reinforcing the current values implies the promotion of action that permeates these filters and are simultaneously not in the purview of the company's management.

Originality / Value: The study also pointed out the pertinence of the use of storytelling for knowing the actors' interpretation about the values of the organization.

Keywords: Organizational Culture; Values; Internal Public; Grounded Theory. 


\section{INTRODUCTION}

There is a certain circularity in the idea of values that are learned in a company's daily routine, be it in the following of procedure or in the creation of processes and products. While the word may refer to a pattern reflected in the social systems of knowledge, ideology, values, laws and daily rituals, it may also refer to the degree of refinement of such systems of beliefs and practices. This means that an organization may sow a pattern of conducts and behaviors from their values. These in turn may influence professionals and be influenced by them (Hofstede, 2001; Almeida, 2009; Baumgartner, 2009; Morgan, 2010; Máynez-Guaderrama et al., 2012).

We have studied an engineering company with over fifty thousand employees, with activities in several Brazilian states and abroad. Given to its capillarity and diversity in professional specialties, it can be inferred that this culture is permeated by many subcultures, which increases the complexity of this cultural system, as well as the challenge of adding value to diversity within a unit (Muzzio and Costa, 2012).

In order to contribute to the debate of constructing a system of common significance and understanding organizations as cultural phenomena, Morgan (2010) suggests queries such as:

"What are the common interpretative schemes that make an organization possible? From where do these schemes come from? How are they created, communicated and maintained?". (Morgan, 2010, p. 135).

The author reminds us that, in the light of a representative view of culture, the social realities of organizations are constructed in a special manner and are much more present in the minds of its members than in concrete sets of rules and relationships. This conception of culture is aligned with the concept of symbolic interactionism, which presumes that people interact with things according to the significance they attribute to them; this significance arises through social and linguistic interaction; and lastly, they are utilized and transformed through the action of subjects as they face various situations (Charmaz, 2009; Dewey, 1933).

On the other hand, as businesses and management systems are organized, many companies start only considering their strategies and adaptation needs towards the market, issuing statements that disregard the level of organizational culture which support their activities. For these statements to express themselves into action, it is necessary for them to integrate people's interpretations and construction of significance. In a study specifically on the relationship between incorporating new practices, work routines and the fundamentals of culture, Bertels et al. (2016) identified that the culture shapes, alters and transforms new practices and routines according to their own foundations. If there is significant misalignment between the action strategy defined by the culture and the new desired behavior, these are reinterpreted and adjusted by the members. Likewise, awareness of the values, behavior and habits consolidated in a culture has become the center piece of management, especially while implementing a strategy (Baumgartner, 2009; Schein, 2010; Naranjo-Valencia and Calderón-Hernández, 2015).

The long-standing institutional relationship of some authors of this article with the company surveyed has given rise to the perception that the values declared by the organization somehow reflect those shared by the employees. This reflection however, is permeated by several layers of symbolic interpretation created through interaction and problem solution, which in turn hinders the explicit expression of the declared values. Our perception is that the formal statements of the organization are part of the language used in construction of significance, which expands as it is used by its members. The contact with the texts written by the employees and submitted voluntarily to the knowledge management program has revealed the existence of a rich array of empirical material which portrayed not only the level of expressed beliefs and values, but also the level of basic premises of organizational culture (Hofstede, 2001).

Thus, the present qualitative study aims to explain how the values expressed by the authors of the narratives converse with the organizational culture stated by the company. What elements impact the dynamics of interpretation of organizational culture values? How to incorporate in the company values that leaders deem important but are still not fully shared among employees?

This work seeks to contribute to the debate around the learning and permeability of organizational culture. Some polarities are presented in this debate, and among them is the knowledge of how manageable cultures are; if the strategy must adapt to culture; how the socialization of behavior process happens and what is the role of individuals; what are the limits and potentialities of leadership in shaping (or being shaped by) organizational Culture (Fleury and Fischer, 2009). We still need to consider the hypothesis that Corporate or Organizational Culture constitutes a subculture within the culture of society in general, especially in the case of companies in the capitalist culture (Oliveira, 2009).

This study presents clues about the mechanism of interaction between the formal statements of the company's command structure and the interpretations constructed 
by the individuals through the social interaction within the institution throughout its history. Although the texts analyzed have been produced for an institutional campaign, whose participation already presents a strong adherence to the statements in narrating concrete cases of actions, they end up revealing their interpretative scheme and their interactions. In addition, this study adds to the necessary accumulation of empirical research on this topic in Brazil, which is still rather precarious (Fleury and Fischer, 2009) and proposes a new methodological approach based on Grounded Theory that, when prioritizing empirical field data, can generate new insights for organizational culture studies. By studying the forms of interaction and significance-construction through symbolic interactionism, we can open windows of interpretation of this phenomenon and seek new reflections on how acting in culture can also assist in the management of change.

This study will be presented in four parts. In the theoretical references, concepts of culture and organizational culture are cited and the importance of these elements for the management of an organization is described. In sequence, the assumptions of Grounded Theory are presented, which based the methodology of this work. The third part brings together the analysis of the data and, finally, the conclusions, which synthesize the contributions of the work.

\section{THEORETICAL FRAMEWORK}

Anthropologists were the first scholars to appropriate the word Culture to define customs, beliefs and values that, once shared, conform a set of patterns and behaviors of a group at any given time and place. According to Freitas (2007), about 160 concepts of culture were cataloged and portray three main currents: i) cognitive anthropology, in which culture is considered as a set of knowledge shared by a group; (ii) symbolic anthropology, which emphasizes the common meanings of the group, and (iii) structural anthropology, which studies the unconscious psychological processes as a universal projection of the mind (Morgan, 2010; Hofstede, 2001).

As a subject of management's interest, the organizational culture starts to draw attention in the 80 's, when magazines aimed at corporate audiences publish works by authors that approach the theme in a theoretical-practical way, showing that some characteristics of successful companies could be reproduced in other organizations. Learning about companies' internal values, their role and the key changes to the creation of a strong culture were themes studied by American professionals interested in building an organizational symbolism that would help them repeat the success of Japanese companies (Freitas, 2007; Almeida, 2009; Pérez López, 2012; Barreto et al., 2013; Muzio, 2017).

Authors like the American Edgar Schein, PhD in Social Psychology, and Dutch Geert Hofstede, PhD in Social Sciences, have become references in numerous studies in this area. In 1984, the book "Culture's Consequences: international differences in work related values" was published, in which Hofstede conceptualizes culture as a collective programming of the mind, manifested in layers, with values being in a more internal and invisible part, while in external ones (from the inside out) are the rituals, heroes and symbols. The latter are visible to outside observers attentive to group practices, although they are not always able to decipher the values that make up the core or essence of culture and are more easily perceived by members of the culture.

The mental programming has three parts, one exclusive to each individual, that is not shared even by two twins; a collective part, common to a group; and a universal part, which can be found in almost every culture. The boundary between these parts and how each can influence the other is unclear. In order to analyze this programming, two constructs are essential: values and culture. This mental programming has been developed in the family environment since childhood, reinforced by school and organizations and contains a component of the country's culture (Hofstede, 2001).

Edgar Schein published the book "Organizational Culture and Leadership" in 1985 and it reached its fourth edition in 2010, which contained studies on the role of leadership as a culture educator, a tool for achieving business goals. In this last update, Schein added reflections of different levels of analysis, from the national and ethnic macroculture to the microculture of groups. The author, however, maintains the ideas that leaders are architects of culture; and once formed, cultures influence the type of leadership possible as well as the idea that, as the elements of culture become inoperative, the leader can and must do something to accelerate change.

For Schein (2010), culture is a dynamic phenomenon and a structure that influences us in many ways. It is constantly reproduced and created by our interactions with others and formed by our own behavior. At the same time, culture implies stability and rigidity in the sense that we perceive, feel, and act in a given society, organization, or occupation. According to what we have learned in the various experiences of socialization, this structure of rules becomes a prescription for the maintenance of social order. The rules allow us to predict behavior, relate to each other, and find meaning in what we do. It is precisely this predictability that keeps the group stable and resistant to change. 
A review of anthropological concepts contributes to a deeper understanding of organizational culture. For this study, we delved into the concepts of values; beliefs and assumptions to make a reading of these elements from the narrative of the employees of an engineering company about their activities in the face of the values declared by the company (Freitas, 2007; Cujar Vertel et al., 2013).

Values represent philosophies considered as important references of behavior for the success of the organization. Once defined and replicated by leadership, values can be assimilated by other members in communicating what is accepted or not by the organization. These guiding principles create, to some extent, mental models or ways of thinking in the organization (Schein, 2010). In addition to the collective aspect, however, there is an individual aspect of the values that are absorbed since childhood, and are therefore often not rational, although people understand them as such. In the same way, values can present conflicts; that is, events in a sphere of life can activate latent values and affect behavior in other spheres of life (Hofstede, 2001). In an organization, values also communicate to outside audiences what to expect from the company. Once shared, they have the merit of raising commitment, as it is associated with personal success and facilitates the connection between organizational and stakeholder goals. Values can be translated and reinforced through stories, rituals, ceremonies and norms, and leadership plays an important role in favoring organizational learning. The culture focuses on the transfer of tacit knowledge and evidences the capacity of absorption and creation of new knowledge, creating a virtuous circle between culture and learning (Hofstede, 2001; Schein, 2010; Máynez-Guaderrama et al., 2012; Bedani, 2012; Pérez López, 2012).

Like values, taboos guide behaviors, but instead of expressing the desired forms of thinking and acting considered correct by the group, taboos refer to prohibited areas: that which should not be allowed or even mentioned. The taboos encompass issues that cause embarrassment, such as misconduct, prejudice, breaking norms, or ignoring moral or ethical aspects. This explains, in part, why companies in general do not speak about and sometimes deny the existence of taboos, a muted element (Freitas, 2007).

Beliefs or assumptions are used to express the "truth" of the organization, one that is not questioned or discussed. It is introjected into minds, as if it were part of nature or as if it formed a collective programming of it. In general, beliefs shared by leading organizations reflect the importance of personal improvement, valuing people, quality of products and services, innovation, communication, profits, among other aspects. For the discourse to move along with the practice, there is a need to reinforce these beliefs and assumptions that subtly influence the daily routine of the organization. In case of success in solving the problem, these assumptions are considered correct and are validated by the group in similar situations in the future, becoming part of the routine. This absorption of knowledge through experiences is the process of cultural learning. The absorbed assumptions make the culture stable, reducing dissatisfaction and anxieties in the face of uncertainties, which reinforces the importance of culture for organizational management (Choo, 2006; Schein, 2010; Loch et al., 2013).

In addition to sharing experiences, large companies care to count and retell their narratives internally and to external audiences as a way of publicizing and sustaining their identity. These narratives tell stories about values, their trajectory and traditions which can project an image, a way of seeing and explaining what they produce and how they work. A study of cultural identity, however, should also consider people's reporting of the processes and practices in which they are involved, and how they are portrayed to themselves and to others, which is a reinterpretation, a version of the group's participants. Several intertwined themes interfere with and define the limits of the interpretation of corporate stories. Understanding this perspective creates and accordance between the values declared by higher positions in the company and the values practiced (Junquilho and Silva, 2004; Taylor and Carroll, 2010).

Culture, built throughout the company's history, is a set of thoughts and responses learned and shared by the group. The strength of culture can be verified in the process of learning and internal and external adaptation that has accumulated. According to Schein (2010), the more emotionally intense experiences the group shares, the stronger the culture. On the other hand, stabilizing these learned cultural elements can pose a risk as the group loses the ability to adapt and set new standards in environments that require change. The challenge is to not lose the ability to learn and adapt in order to innovate and be sustainable (Hofstede, 2001; Choo, 2006; Fleury, 2009; Schein, 2010; Bueno and Freitas, 2015).

The care that must be taken in observing a culture is that these elements are not always visible, even by the members of the group that share the same system of thoughts and behaviors, simply because they do not ask themselves about the concepts or the logic behind what they do. It's as if everything were inadvertedly obvious or familiar. Likewise, it is difficult to know if a particular behavior reflects national, educational, professional or organizational values, since culture is multifaceted. Individuals can occupy several cultural spaces and draw their values from various sources (Cujar Vertel et al., 2013; Muzzio and Costa, 2012). 
There are, according to Schein (2010), three levels of depth, which lose their visibility as they move away from the surface. At the deepest level are the basic assumptions, which are the "truths" that are out of the question, non-negotiable, and followed without question. This is exactly why they are not re-evaluated and are beyond the reach of change. Those who do not follow them will be considered foreign, mad or become rejected by the group. At this depth are the beliefs, thoughts and feelings that are considered appropriate and guide the group. In the words of the author,

culture as a set of basic assumptions defines to us what we should pay attention to, the meaning of things, how to react emotionally to what occurs and what actions to take in various kinds of situations (Schein, 2010, p. 30).

If misunderstood or perceived differently, assumptions become triggers for communication failures and conflicts, and by not sharing the same assumptions or the same meanings, group stability can be broken, something very common in multicultural organizations or groups. In addition, individual and technical skills and organizational strategy are developed according to the values accepted by the organization (Fleury, 2009; Bueno and Freitas, 2015; Muñoz and Castillo, 2013).

In the intermediate position are the assumed values (strategies, goals, philosophies) that are strongly influenced by the leadership or the founder, especially after the presented solutions are perceived as a reason for success and finally shared as a validated recipe or an example to be followed. In the beginning, the beliefs and values disseminated by the leader influence trust and play the role of reducing uncertainties but are validated only after testing or living experience. As they present results and are supported by assumptions, norms and rules, these assumed values can migrate to the level of basic assumptions. When the assumed values differ from the basic assumptions of the group and the previous learning of the individual, it is common to observe a distance between what is spoken and what is practiced. In contrast, when the two levels are integrated, this can serve as a source of identity and a central mission. Hence comes the need to build values, not only based on a "values statement" written by management, but to establish a "letter of intent", which expresses the principles of the organization, the experiences, and meanings of the organizational actors (Junquilho and Silva, 2004; Schein, 2010).

At the most superficial level are the artifacts, which cover everything that is seen, heard or felt when one comes across a group whose culture is unfamiliar. Among the artifacts are the products, language, technology, emotional and artistic manifestations, myths and stories of the organization, its explicit list of values, rituals, ceremonies, among others. Although they are visible and easily observable elements, they are the most difficult to decipher, according to Schein (2010). This is because the observer describes what they see and feel without specifying how much his account translates the meaning to the group or reflects shared basic assumptions. The author admits, however, that physical artifacts such as architecture or clothing can lead to the identification of original images and metaphors that reflect the deeper levels of culture when the organization in question forms part of the wider culture of the researcher. The problem is that the interpretation can be ambiguous, the insight can be tested, and the meaning validated by someone who has experienced the culture at the level of values and deeper assumptions.

Although this theoretical accumulation on how organizational culture is constituted, consolidated and updated has generated a great leap in studies of this theme, it has become even more urgent, considering the speed of the transformations generated in the environment and the need of adaptation of the organizations. Internationalization, mergers, transformations in technology, processes and products have put the fundamentals of culture in check. If, on the one hand, a strong culture supplants subcultures, creates fluidity in communication and synergy in actions by a strong sharing of meanings, on the other hand it forms part of the mental model that can constitute a good part of the difficulties of adaptation, precisely because they are at the levels of uncontested truths (Senge, 2013).

\section{NARRATIVE SELECTION}

Narrative Selection is a knowledge management initiative within the company's human resources sector that aims to identify, record, select, recognize, and disseminate stories about employees' knowledge and professional experiences. The second edition, used in the present study, was carried out in 2016.

Employees were invited to submit stories that had brought about relevant contributions to the company, in their own discretion. They could be facts, actions, projects and initiatives of a professional nature, having as its theme the word "overcoming". Employees that could apply include the ones in the company as a whole, the holding, subsidiaries and companies abroad. Participation was not extended to service providers, trainees, retirees and members of management involved in the initiative, members of the Knowledge Management Commission and members of the Multifunctional Assessment Committee. 
The overall purpose of the action is stimulate the practice of registration and sharing of knowledge and experiences. In the long term, the idea is to promote a cultural change that values the practice of Knowledge Management in the company's daily life. The initiative's regulation provides information on the evaluation criteria carried out by a Multifunctional Committee made up of employees of various training and areas of activity in the company.

The narratives were written in such a way that, in addition to the author's identification, included three key words, a summary of up to 200 words and the story itself. There was no limit to the number of pages, nor to the date on which the reported work was performed by employees.

\section{METHOD}

The analytical procedures of this study were based on the systematics of Grounded Theory. The qualitative approach was more adequate to the study as individual narratives sought to explore the elements that might be related to the company culture. This depended on "reading the voice" of people. Grounded Theory proved appropriate for the research due to the existence of a rich collection of texts written by employees with reports about their activities in the organization. These reports brought values and cultural practices embedded in the experience in the company. These elements could be transformed into codes that would help explain how the values of the organizational culture interact with the values expressed by the internal public through their writing (Charmaz, 2009; Creswell, 2014).

The analysis process began with the identification of the 10 values declared in the institutional texts. These values are represented by the following expressions: Sustainable Development, Integration, Results, Readiness for Change, Entrepreneurship and Innovation, Ethics and Transparency, Respect for Life, Human and Cultural Diversity, People and Company Pride.

Twenty-five texts enrolled were selected in the Narrative Selection as they represented the activities of the company's production chain in various regions of Brazil and the world. The first reading contributed to an initial or open coding, in which similar or divergent points found in the narratives were identified according to each category. In the course of the readings, information about the position occupied by the narrator in the company, the date/context of the narrated fact, the mention of personal history, excerpts that denoted the relation between hierarchical levels and highlights about creativity were added to this open codification.
Following this stage, a comparative analysis was performed, carried out in an Excel spreadsheet, in open coding. This analysis resulted in focused or selective coding, as the method describes, searching for the most significant or frequent codes, and a visual model identifying the relation of paradigms to the central phenomenon, that is: in the dialogue between company values and values of employees. Selective coding implies deciding which codes can be considered as conceptual categories that explain ideas, events or processes (Charmaz, 2009; Ferreira and Felizola, 2012).

The corpus verified in this study began to show signs of saturation from the analysis of the 21st narrative, because all elements began to become repetitive and not to add information to the analysis. The analytical procedure continued until 25 texts were completed, at which point the categories were considered to be saturated (Charmaz, 2009).

The constructivist perspective of Foundational Theory, according to Charmaz (2009), expresses the possibility of hidden aspects being brought to the surface due to the researcher's experience and interpretation, or self-reflexivity, according to Yin (2016). For the authors of this article, the theory does not emerge solely from data, but also from the process of interaction between researcher and respondent (Charmaz, 2009; Creswell, 2014; González-Teruel, 2015).

One of the limits of the research, considering this corpus, is due to the fact that, when choosing to participate in the Narrative Selection, the employees write stories that portray successful work. In general, the problems cited are exposed only to contextualize the solutions, there are no process errors, inherent business risks or unethical practices, which does not mean that these do not exist. Likewise, the narratives do not portray the taboos, which are considered elements for the analysis of the organizational culture (Freitas, 2007).

\section{DATA ANALYSIS}

In the first readings, when we tried to capture what the narrators mentioned about the categories defined by the company as organizational values, it became evident that not all concepts were apprehended in the same way, which is in agreement with the theoretical references that deal with culture as experiences (Hofstede, 2001; Choo, 2006; Senge, 2013).

The "sustainable development" value defined by institutional texts as a long-term business perspective, contributing to the economic and social development for a healthy environment in the communities in which it operates, touched only projects or activities that had a direct relationship with the environment or with proposals 
for cost reduction. A single employee questioned whether a particular resource needed to develop a technology for operational use would have a significant impact on the environment.

"Human and cultural diversity", valued as a way of guaranteeing the principles of respect for differences, non-discrimination and equal opportunities, was mentioned only by narrators who lived through experiences with international projects or had a direct relationship with communities around the operations. There was no mention, for example, of the human and cultural diversity represented by employees from the five regions of Brazil that interact in the company.

The search for the maximization of collaboration and the capture of synergies between teams, areas and units, translated into the value of "integration", was mentioned in the narratives of employees whose work had a relationship of rendering service from one area to another or tending to emergencies. The corporate areas and the research center, which acts as a service provider for the corporation's business areas, reveal themselves as the major promoters of this integration.

"Respect for life", in all its forms, manifestations and situations, is a value and also a principle of the code of ethics, a document that integrates the most superficial part of culture (Schein, 2010). Through this value, the company reaffirms its attention to health, safety and environmental issues. Respect for life can be illustrated by the interruption of seismic work to provide help to a young country woman who had crashed near the topographic line, or by the choice of cotton material (for less impact on the environment) of the Brazilian flag used in a commemorative campaign from the company. Another common ethical principle among the narrators was loyalty to the company, expressed by zeal and discipline in the job and in dealing with human beings and material and immaterial goods.

These comparative analysis on each category allowed for the creation of an initial or open coding, which reveals the most relevant aspects of each value of the company, according to the authors of the narratives (Table 1)

Table 1: Initial or open coding

\begin{tabular}{|c|c|}
\hline Company Values & Initial or Open Coding \\
\hline \multirow{2}{*}{ Sustainable Development } & Economic \\
\hline & Environment \\
\hline \multirow{3}{*}{ Integration } & Service rendering \\
\hline & Joint projects \\
\hline & Emergency action \\
\hline \multirow{3}{*}{ Results } & Operational/Financial \\
\hline & Image \\
\hline & People qualification \\
\hline \multirow{2}{*}{ Readiness to change } & Improving processes \\
\hline & Changing routines \\
\hline \multirow{2}{*}{ Enterpreneurship and Innovation } & Technology \\
\hline & Management \\
\hline \multirow{2}{*}{ Ethics and Transparency } & Loyalty \\
\hline & Respect for life \\
\hline \multirow{3}{*}{ Respect for life } & Life and death situations \\
\hline & Post-accident \\
\hline & Preventive care \\
\hline \multirow{2}{*}{ Human and Cultural Diversity } & International activity \\
\hline & Community relationship \\
\hline \multirow{2}{*}{ People } & Valuing through trust from the hierarchical superior \\
\hline & Valuing through high performance teamwork (team acknowledgement) \\
\hline \multirow{2}{*}{ Company pride } & Pride in accomplishing \\
\hline & Pride in belonging \\
\hline
\end{tabular}


To these codifications were added descriptive information, such as the position occupied by the narrator in the company, date/context of the story, insertion of personal stories, relationship between hierarchical levels and highlights about creativity. This is because they contribute to understanding the context in which the values are mentioned.

Some facts marked changes in the procedure and in the habits practiced by the company. The narrators of the Narrative Selection mentioned an environmental accident of large proportions, the discovery of natural resources, the economic crisis of 2008, a corporate crisis with international repercussions and the application of the Act for Quotas for Black Persons in the company's application process.

Also recurrent in the narratives was the insertion of personal stories, from the title to the contextualization. Thus, the narrative "(Company's name) and I" showed the projects carried out by a systems analyst to stabilize the Internet connection of the office in the United States with headquarters in Rio de Janeiro and "Newly married in Libya" narrated the rush of an employee who returned from the honeymoon trip, changed his suitcase and traveled to a mission in Africa. Some speak about realizing dreams, family references, feelings of pride for belonging to the company, expressed in sentences like: "What motivated me to have this conduct and to persist was the indignation in thinking that harm could come to the company"", "We are a company that's very important to Brazil" and "We need to strengthen ourselves as the basis of Brazilian society and economy and we cannot allow it to weaken".

In writing about their activities, employees indicate that the routine is impacted - both internally and externally to the company. Moreover, both organizational aspects and individual experiences interfere with how employees reinterpret the values declared by the company (Hofstede, 2001). In this way, we extract from the data four factors that function as a kind of filter through which the company values pass through and are absorbed and reinterpreted by the group. They are: the social-economic context, the particularities of the industry and the company, the nature of the activity developed and the personal and professional experience of the narrator.

These factors, indicated in Figure 1 as focused or selective coding (Charmaz, 2009), are represented as sets, whose intersections indicate that employees may have different understandings of company values, depending on the perception of each of the factors and the correlation between them. These are not different interpretations of the same value, but of the experiences that influence the absorption of knowledge and values that are predominant in the narratives.
Based on the previous analysis, the following graph has been constructed to express the substantive theory, as Charmaz (2009), as presented in Figure 1.

This explains why professionals who deal directly with the community are closer to the value of human and cultural diversity than those in industrial operation, as the latter are focused on operational efficiency. In Rio de Janeiro, a nurse who was dedicated to building knowledge management dynamics for good health care practices; the social worker from Amazonas who persuaded her superiors towards a project to eradicate illiteracy among outsourced workers; and a communicator who led the annual internal accident prevention campaign in a municipality in Rio de Janeiro. These individuals are united by the value of entrepreneurship and innovation. But perhaps these projects do not have the same value for the equipment engineer, who used his atomization knowledge to develop equipment for producing a special chemical.

At the intersection of all sets (Figure 1), very representative values were found in the narratives, such as "zeal for work" and "respect for life". In the values declared by the company, this would be only a part of the principles embedded in the value "ethics and transparency". Other principles of the Code of Ethics can be found in the stories, but they did not appear with the same frequency, which leads us to infer that they would not be in the central core of values relevant to employees.

Another central point is the "value given to people by the relationship of trust". The value "people" is tied to the "development of the professionals" for the company. It is not clear whether this concept is linked only to the updating and qualification of the professionals or if it includes opportunities to integrate projects in which the knowledge acquired can be applied. The code of ethics of the company set out in principle VIII speaks of the commitment to respect and appreciation of people in their "diversity and dignity", without clarifying the issue. The texts of the narratives show that it is through the relationship of trust given to them by the hierarchical superiors in their work capacity and recognition of their teammates in their ability to contribute that employees feel valued. Statements like "After explaining the plan to him [the boss], he fully supported the idea and gave me the green light to proceed with the new project" and "I was fortunate enough to go [to the seismic work] with the company's best geologist. I, however, was just a young geophysicist with few years of experience. Very clever; but young", express the feeling of satisfaction gotten through the relationship of trust.

Hierarchical levels are linked to the role of those who approve, and it is not always clear whether employees 


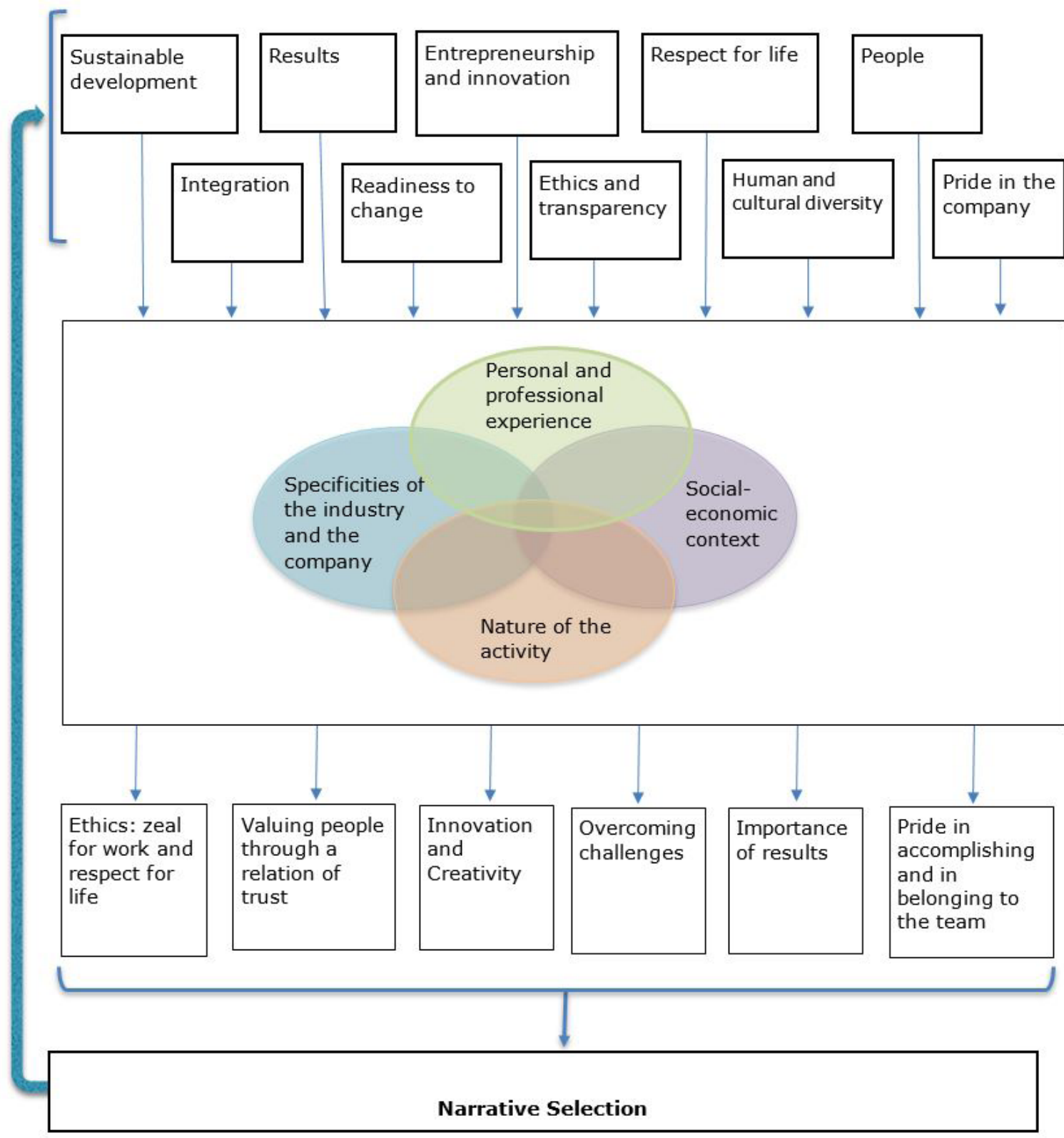

Figure 1: Substantive theory on the interpretation of the values declared by the company according to the employees' narratives

participate in decisions. Some narratives show that suggestions are welcome, but the management level decides and distributes activities. According to Schein (2010), this is the level of basic assumptions, the one that is less visible in the organization, because they are unconscious beliefs, perceptions, thoughts and feelings in the organization. An environmental technician, for example, said he was "summoned" to clean a beach in Paquetá during a major environmental accident, and despite the 28 days away from the family, he says it was "worth the experience", but under no circumstances he considers the possibility of having the initiative to participate in solving an emergency situation.
Another experience was recounted by a communication professional who had a press relations project rejected by his superior. He waited for 10 years to implement it, and only did so after becoming a manager and able to make the decision. It is noteworthy that there was no mention of his team's participation in the success of the project, indicating that he may have reproduced the basic assumptions of the hierarchy culture (Schein, 2010; Choo, 2006).

According to Freitas (2007), the founders and leaders of an organization have a crucial responsibility in the creation, development and maintenance of its culture. In addition, 
we must consider the need to manage what Chao and Moon (2005) call cultural tiles, to show that individuals are motivated by multiple sources that form mosaics, which imply multiple cultural identities. The actions of the leader should favor the creation of a shared vision (Chao and Moon, 2005; Muzzio and Costa, 2012; Muzio, 2017).

The factors or filters highlighted in the selective coding of this study, however, showed that there are more complex aspects to be managed by leaders, such as the social-economic context or even the specificities of the industry that may require ways of thinking and acting different from those shared in the organization. Meeting the challenge of learning and adapting to the changing world, as suggested by Choo (2006), requires special attention to filters related to the personal and professional experience of employees associated with the nature of the activities they perform in the organization. Along these lines, the leadership performance is relevant but also limited.

Inspiring managers lead people and teams to overcome hardship. In other words, "It is the responsibility of good leaders to keep their words attached to the meanings and ideals they represent" (Catmull, 2014, p. 10). The research by Junquilho and Silva (2004). In the Post and Telegraph Company was also identified the need for a process of collective debate between top management and organizational actors in order to bring the practices and meanings of those desirable principles of the organization closer together.

\section{CONCLUSION}

This study sought elements in the texts written in the $2^{\text {nd }}$ edition of the Narrative Selection that allowed for a deeper understanding of at least part of the dynamics of the relationship between the values of professionals and those declared by the company. In addition to these texts, data analysis considered the company's official website and the company's 2015 Sustainability Report, valid at the time of this study, as sources of information.

The constructivist perspective of the Grounded Theory, systematized by Charmaz (2009), was used as a reference in the research procedures. The corpus was composed by 25 essays written by the employees of the company under study through the Selection of Narratives of 2016, which provided a sufficient number of stories to saturate the analysis. From these constructs, it was possible to identify at least four sets of elements that are interconnected. These sets function as a sort of filter through which employees absorb company values according to their own values and bring to light the perceived or interpreted values that are captured in their individual experiences and are effectively practiced in the company.

This interpretation does not translate into a homogeneous whole, because the individual and sub-group experiences that operate in different regions and activities of the production chain give rise to different perceptions of reality. This shows that individuals draw different and simultaneous facets to behave according to the social environment and adapt to the group, apparently creating a mosaic whose pattern reflects the basic colors of organizational values.

Thus, the research revealed that organizations can better manage the cultural diversity of their workforce in order to activate facets that are coherent and can reinforce the key values of the organization, knowing that culture will not be a homogeneous whole because of their national, regional and local influences, which are interpreted and re-signified.

The analytical strategy of the research identified six values that, considering consistence, were marked as essential values for employees. This does not mean, however, that there are no other important values, depending on the nature of the project, the academic background and experiences of the professional, the social-economic context or specificities of the industry and the company, just that they would not figure in the core values under any circumstance.

These values are aligned with the values declared by the company, although there are some differences. Overcoming challenges, for example: for the company, it is linked to technological innovation, while for employees it is also about meeting deadlines and goals with innovation in management and emergency response. Innovation, in the perspective of employees, is not only in business or technology, but also in management. This evidence in the research, in addition, points to a convergence with the studies that are bringing the analysis of the innovation potential of a company closer to its organizational culture. Reviewing the bibliography of this relationship between organizational culture and innovation, Bruno-Faria and Fonseca (2014) point out that the main conclusions are that these relations are quite strong. In general, basic values and assumptions indicate a greater relationship with the capacity for innovation than artifacts and symbols are capable of. The narratives of this study confirm that management practices based on basic assumptions have a greater relation to this value than policies and statements - which are at the artifact level.

Knowing these characteristics is important so that the organizational culture can be an ally in the accomplishment of the objectives of the company. Organizational leaders play a crucial role in creating, constructing and reproducing the thoughts and feelings that move the inner public, because 
the organization's way of being is not a work of chance, although some values are reproduced on an unconscious level. In order to insert, reform, reinforce or even exclude a value from a particular culture, it is not enough to put it in words, but rather to express it in actions that impact the dynamics of the filters, and this is no simple task. It's a job that needs to be done every day. On the other hand, the role of leadership does not exclude the need to maintain a process of dialogue with organizational actors to approximate values and practice, considering the different points of view that, in a circular way, impact the renewal of cultural values.

The study also pointed out the pertinence of the use of narratives (storytelling) for knowledge and analysis of the interpretations given by the actors, mainly in the way in which they justify the actions and their results. The strong relationship with some of the firm's stated values points out how much the shared language ends up being incorporated into the social interactions that come to generate meanings.

This work, although it has been systematically carried out in the role of leadership, did not specifically focus on the participation of leadership in this dynamic of the organizational culture of the company. Given the importance of the subjects to the theme, specific studies are recommended on how these values are built and rebuilt by the organization's leaders, managers, or decision makers.

\section{REFERENCES}

Almeida, F. (2009), "Os valores pessoais e o comprometimento social dos gestores: um estudo sobre a Responsabilidade Social das empresas no Brasil", Revista Crítica de Ciencias Sociais, Vol. 86, available at: https:// journals.openedition.org/rccs/259 (accessed 14 May 2017).

Barreto, L.M.T., Kishore, A., Reis, G.G. et al. (2013), "Cultura organizacional e liderança: uma relação possível", Revista de Administração, Vol. 48, No. 1, pp. 34-52, available at: http://www.scielo.br/pdf/rausp/v48n1/04.pdf (accessed 12 June 2017).

Baumgartner, R.J. (2009), “Organizational culture and leadership: preconditions for the development of a sustainable corporation", Sustainable Development, Vol. 17, No. 2, available at: https://onlinelibrary.wiley.com/doi/ abs/10.1002/sd.405 (accessed 10 June 2017).

Bedani, M. (2012), "O impacto dos valores organizacionais na percepção de estímulos e barreiras à criatividade no ambiente de trabalho", RAM, Revista de Administração Mackenzie, Vol. 13, No. 3, available at: http://www. scielo.br/scielo. .php?script=sci_arttext\&pid=S1678-
$69712012000300008 \& \operatorname{lng}=e n \& n r m=i s o \& t \mid n g=p t$ (accessed 20 June 2017).

Bertels, S., Howard-Genville, J. and Pek, S. (2016), "Cultural molding, shielding, and shoring at Oilco: the role of culture in the integration of routines", Organization Science, Vol. 27, No. 3, pp. 573-93. http://dx.doi.org/10.1287/ orsc.2016.1052.

Bruno-Faria, M.F. and Fonseca, M.V.A. (2014), "Cultura de inovação: conceitos e modelos teóricos", RAC. Revista de Administração Contemporânea, Vol. 18, No. 4, available at: http://www.scielo.br/scielo.php?script=sci_ arttext\&pid=S1415-65552014000400372\&lng=en\&nrm =iso\&tlng=pt (accessed 12 June 2017).

Bueno, J.M. and Freitas, M.E. (2015), “The multicultural teams in brazilian subsidiaries of multinational companies: a multiple case study", Organizações \& Sociedade, Vol. 22, No. 72, available at: http://www.scielo.br/scielo. php?script=sci_arttext\&pid=S1984-92302015000100015 (accessed 10 June 2018).

Catmull, E. (2014), Criatividade S.A.: Superando as Forças Invisíveis que Ficam no Caminho da Verdadeira Inspiração, Rocco, Rio de Janeiro, RJ.

Charmaz, K. (2009), A Construção da Teoria Fundamentada: Guia Prático para Análise Qualitativa, Penso, Porto Alegre, RS.

Chao, G.T. and Moon, H. (2005), "The cultural mosaic: a metatheory for understanding the complexity of culture", The Journal of Applied Psychology, Vol. 90, No. 6, available at: https://pdfs.semanticscholar. org/51ba/4e408afa473fdb4d8746e3e8fb0eb1642815.pdf (accessed 28 April 2017).

Choo, C.W. (2006), Organização do Conhecimento: Como as Organizações usam a Informação para Criar Significado, Construir Conhecimento e Tomar Decisões, 2nd ed., Senac, São Paulo, SP.

Creswell, J.W. (2014), Investigação Qualitativa e Projeto de Pesquisa: Escolhendo entre Cinco Abordagens, 3nd ed., Penso, Porto Alegre.

Cujar Vertel, A.C., Patermina, C.D.R., Riaño, H.E.H. et al. (2013), "Cultura organizacional: evolución en la medición", Estudios Gerenciales, Vol. 29, No. 128. available at: https://www.sciencedirect.com/science/article/pii/ S0123592314000126 (accessed 20 May 2017).

Dewey, J. (1933), How We Think, D.C. Heath and Co., London, UK.

Ferreira, R.M.C. and Felizola, M.P.M. (2012), "Teoria Fundamentada em Dados: uma experiência metodológica", 
Revista Latinoamericana de Metodología de la Investigación Social, Vol. 3, No. 2, available at: https://proceedings.ciaiq. org/index. php/ciaiq2017/article/view/1368 (accessed 18 May 2018).

Fleury, M.T.L. (2009), "Organizational culture and the renewal of competences", Brazilian Administration Review, Vol. 6, No. 1, available at: http://www.scielo.br/scielo. php?script=sci_arttext\&pid=\$1807-76922009000100002 (accessed 15 May 2017).

Fleury, M.T.L. and Fischer, R.M.L. (2009), Cultura e Poder nas Organizações, Atlas, São Paulo, SP.

Freitas, M.E. (2007), Cultura Organizacional: Evolução e Crítica, Thompson Learning, São Paulo, SP.

González-Teruel, A. (2015), “Estratégias Metodológicas para la Investigación del Usuario en los Medios Sociales: análisis de contenido, teoría fundamentada y analisis del discurso", El Profesional de la Información, Vol. 24, No. 3, available at: http://www.elprofesionaldelainformacion. com/contenidos/2015/may/12.html (accessed 10 July 2017).

Hofstede, G. (2001), Cultures Consequences: Comparing Values, Behaviors and Organizations Across Nations, 2 nd ed., Sage Publications, London, UK.

Junquilho, G.S. and Silva, A. (2004), "Carta de Valores Versus Carta de Intenções: Uma Reflexão Sobre a Abordagem Integrativa da Dimensão Cultural em Organizações", Organização \& Sociedade, Vol. 11, No. 31, available at: https:// portalseer.ufba.br/index.php/revistaoes/article/view/10711 (accessed 15 May 2017).

Loch, C.H., Sengupta, K. and Ahmad, M.G. (2013), "The microevolution of routines: how problem solving and social preferences interact", Organization Science, Vol. 24, available at: https://dl.acm.org/citation.cfm?id=2434577 (accessed 12 June 2017).

Máynez-Guaderrama, A.I., Cavazos-Arroyo, J. and Nuño-De La Parra, J.P. (2012), "La influencia de la cultura organizacional y la capacidad de absorción sobre la transferencia de conocimiento tácito intra-organizacional", Estudios Gerenciales, Vol. 28, available at: http://www. redalyc.org/articulo.oa?id=21225840011 (accessed 3 June 2017).

Morgan, G. (2010), "A Criação da realidade Social: as Organizações vistas como culturas", in Morgan, G. Imagens da Organização, 1st ed., Atlas., São Paulo, SP.
Muñoz, O.A. and Castillo, R.M. (2013), "Cultura organizacional en una empresa propiedad de sus trabajadores", Cuadernos de Administración, Vol. 26, No. 47, available at: http://www.scielo.org.co/scielo.php?script=sci_ arttext\&pid=S0120-35922013000200011\&lng=en\&nrm =iso\&tlng=es (accessed 19 April 2017).

Muzio, H. (2017), "Indivíduo, liderança e cultura: evidências de uma gestão da criatividade", RAC. Revista de Administração Contemporânea, Vol. 21, No. 1, available at: http://www. scielo.br/scielo. php?script=sci_arttext\&pid=S1415$65552017000100107 \& \mathrm{lng}=\mathrm{en} \& \mathrm{nrm}=\mathrm{iso} \& \mathrm{t}$ lng $=p t$ (accessed 22 April 2018).

Muzzio, H. and Costa, F.J. (2012), "Para além da homogeneidade cultural: a cultura organizacional na perspectiva subnacional", Cadernos EBAPE.BR, Vol. 10, No. 1, available at: http://bibliotecadigital.fgv.br/ojs/index.php/ cadernosebape/article/view/5250/3984 (accessed 25 April 2017).

Naranjo-Valencia, J.C. and Calderón-Hernández, G. (2015), "Construyendo una cultura de innovación. Una propuesta de transformación cultural", Estudios Gerenciales, Vol. 31, No. 135, available at: http://www.redalyc.org/ articulo.oa?id=21237092009 (accessed 25 April 2017).

Oliveira, M.A. (2009), A Face Oculta da Empresa: Como Decifrar e Gerenciar a Cultura Corporativa, Senac Rio, Rio de Janeiro, RJ.

Pérez López, S. (2012), “La influencia del liderazgo sobre el aprendizaje: el papel mediador del contexto organizativo", Revista Innovar Journal, Vol. 22, No. 45, available at: http:// www. redalyc.org/articulo.oa? $\mathrm{id}=81824864011$ (accessed 10 May 2017).

Senge, P.M. (2013), A Quinta Disciplina: A Arte e a Prática da Organização que Aprende, BestSeller, Rio de Janeiro, RJ.

Schein, E. (2010), Organizational Culture and Leadership, 4th ed., Jossey-Bass, San Francisco, CA.

Taylor, J.F. and Carroll, J. (2010), "Corporate culture narratives as the performance of organizational meaning", Qualitative Research Journal, Vol. 10, No. 1, available at: https://www.emeraldinsight.com/doi/abs/10.3316/ QRJ1001028 (accessed 10 June 2017).

Yin, R. (2016), Pesquisa Qualitativa do Início ao Fim, Penso, Porto Alegre, RS. 
Received: 05 Dez 2018

Approved: 22 Dez 2018

How to cite: How to cite: Seixas, M.A.C., Andrade, E.P., Cândido, J.C. et al. (2020), "How to align organizational culture with corporate goals: a study on a large-sized Brazilian engineering company", Brazilian Journal of Operations \& Production Management, Vol. 17, No. 1, pp. 1-13. https://doi.org/10.14488/BJOPM.2020.004 